DANIEL SENISE, 2892: BETWEEN BEING AND NOTHINGNESS,

\section{THE SPECTATOR}

Michael Asbury

ABSTRACT: This essay investigates a work by the artist Daniel Senise entitled 2892, which at first appears to be atypical within the oeurre. It traces the production of compositional characteristics as well as the repetition of themes and figures within other more overtly painterly works produced at the moment of conception of 2892 arguing that there is a contextual coherence within the group as a whole. Whilst almost two decades separate the conception of 2892 and its first public showing, the essay then speculates on some interesting co-relations that exist between the site in which it was shown and the trajectory that the other painterly work concurrently took.

KEYWORDS: Baroque, Duchamp, Neo-classicism, Readymade, Sartre, Self and Other, The Shroud.

In 1992, Daniel Senise initiated a process of painting that would define his practice over the following decades. In the painting Retrato da Mãe do Artista (1992) the outline of a seated figure can be perceived out of the agglomeration of oxidised iron marks; a vague shadow in the background softly emphasises the subject, making pictorial sense out of the apparent randomness of the traces of nails. Another painting produced that same year bears the same title. Only slightly smaller in dimension the painting depicts a seated figure who now appears in what seems to be an empty dark room shrouded by a sheet as if having just passed away.

The following year, a similarly seated figure appears with its mirrored double in Despacho. This time the figures are not concealed by oxidation, nor by a shroud; instead, facing each other, they dominate the composition. Sem Titulo also of 1993, presents the same mirrored seated women, this time concealed by a shadow that envelops everything except the space between them. From this space the shape of a classical, archetypal, vase emerges. In 1994, the same vase reappears, now inverted into the shadow itself, in the painting Casamento where a male and female figure seemingly walk around its rim.

The vase as an image is capable of evoking both the bearer of life as a symbol for the womb and the container of death through the figure of the urn, yet in itself it outlines merely an empty space. Senise's vase is formed by the mirrored image of a body, whose presence - through the figure-background segregation law of gestalt - is duly effaced. The vase can only exist by obliterating this doubled body, by making it a spectre, that is, present but not seen. From these recurring themes, death, memory, the trace and the shroud, it is reasonable to assume that the artist was experiencing between 1992 and 1993 a period of personal turmoil that overflowed into the work and that, in hindsight, would ultimately transform his practice.

Senise held an exhibition at Galeria Camargo Vilaça in 1993. In the accompanying essay entitled 'Sudário e Esquecimento: uma tela de Daniel Senise nos diz que é impossivel esquecer', Paulo Herkenhoff invokes Duchamp in order to discuss the tensions at play in Senise's work.' Suggesting that the background and figure dichotomy is transposed into the duality between world and work, Herkenhoff concludes that:

Na iconografia do Daniel Senise, um fragmento de um quadro, vestigio da historia da arte, é um simbolo Readymade. Marcel Duchamp considerava que tudo partia do readymade, desde a pintura mais pessoal e, no entanto, extraída de um tubo de tinta industrial, até, em última análise, de um de nós, que saímos dos readymades que seriam nosso pai e mãe.

These issues effusing from Senise' 1992-1993 use of readymade symbols, provide a way into discussing a work that he conceived then - but exhibited only this year (201I) - namely 2892. The eighteen years that have elapsed between concept and presentation were perhaps a consequence of what Senise describes as his baroque character, his reluctance to leave things as they are, his desire to rework, to transform:

Herkenhoff, Paulo, in: Daniel Senise, Galeria Camargo Vilaça, São Paulo. Excerpt reprinted in: Daniel Senise: Vai que nós levamos as peças que faltam, Pinacoteca do Estado de São Paulo, 201I, p. 219.

2

lbid. 
Acho que tenho uma resistência para limitar meu trabalho a um tiro só, a uma afirmação tão peremptória.

It is appropriate, then, that the first showing of this work took place in the main lobby of a neoclassical building. Designed by Grandjean de Montigny, the former Casa do Comércio that now houses the Casa França-Brasil, is a vestige of the early $19^{\text {th }}$ century French Neoclassical taste, during the Brazilian Imperial period, and that contrasts sharply with the excess of Colonial baroque. ${ }^{4}$

2892 appears to be an atypical work within Senise's creative trajectory. It is formed by two long white panels. Enigmatically entitled Branco 2430 and Branco 462, these panels were installed along Montigny's neoclassical colonnade, facing each other and forming a long corridor - as if the artist wanted to separate the viewer from the architecture, from the world perhaps. Each of these canvases were formed by the amalgamation of segments that together form a grid. Subtly distinct from one another, one side is formed of almost square segments while the other by narrower rectangles approximately half the surface area of those on the opposing side. These differently-sized segments are in fact stretched double and single bed sheets. Conceived in 1993, the project consisted of donating white bed sheets to a motel and a cancer hospital. At the end of their useful life, the sheets were recuperated, stretched, and placed facing each other; on one side, those used by the motel (2430), on the other those from the hospital (462), forming between them a corridor through which the exhibition visitor walks. Unlike Bruce Nauman's Green Light Corridor (1970) however, Senise's 2892 does not oppress the spectator, there is no forceful containment or restriction, the space between simply exists as a thoroughfare. The numbers - which add up to 2892 , the title of the work - refer to the estimated number of bodies that have passed through each group of sheets. As the captions make explicit, their distinct dimensions are determined by their previous use, by the association of the double bed on one side with sex, and the single on the other, with death. The sheets are not quite readymades. They have undergone a process directed by the artist even if his own hand, or labour, was not involved. We can identify certain marks in these surfaces: stubborn

'Vaso Chinês, entrevista com Agnaldo Farias', in: Daniel Senise 2000-2006, Museu Oscar Niemeyer, Curitiba, 2006. Excerpt reprinted in: Daniel Senise: Vai que nós levamos as peças que faltam, op. cit., p.249

Daniel Senise, 2892, Casa França-Brasil, Rio de Janeiro, 2011. stains, minute holes, areas that have been stitched, the faint traces of wear that betray the purity of their white surfaces. It is not so much a case of leaving the canvas bare, but rather acknowledging the fact that these are surfaces that have been washed, repetitively, again and again, after and against the impressions left by each body. The shroud is not the most appropriate metaphor either; the sheets do not offer any visible sign of the human body, but only signs of wear, traces that cannot be reduced to representations. Yet, while we cannot so easily identify the presence of readymade symbols, as Herkenhoff suggests with other works by Senise, within the limits established by this work, the spectre of Duchamp remains. Octavio Paz described Duchamp's Large Glass (The Bride Stripped Bare by her Bachelors Even) and Given: I The Waterfall, 2. The Illuminating Gas, (Étant donnés: $1^{\circ}$ la chute d'eau $/ 2^{\circ}$ le gaz d'éclairage.) as parentheses between which 'not so much the idea of art as the modern idea of the work of art' was contained. ${ }^{5}$ The placing of the spectator with regard to the work is also revealing:

In the Large Glass, the spectator must imagine the scene of the Bride's delight at being stripped; in Given he sees her in the actual moment of fulfilment. ${ }^{6}$

Octavio Paz's consideration of Duchamp's Large Glass and Given as standing as limits (pre and post coital) does not consider the ambivalence of the female nude in Given, which could either be experiencing 'the moment of fulfilment' or lying there, perhaps even dead, after an episode of violation. Seen under such a light, the machinations of desire and the sexual act become tragically consummated. Senise's 2892 could be understood as associating sex with death, not as the result of violence, but as a homage, or an act of mourning, for the loss of his friend the artist Leonilson, who died the same year this work was conceived. 2892 transcends nevertheless such interpretative reductions because it invokes not the sexual act nor death but that which is between, the life cycle itself. It appeals in this way for philosophical inquiry into the human condition: an invocation that is already implied by its title, which speaks of a multitude of bodies that, like the mirrored woman in his other paintings, remain spectral, invisible. Far from nothingness,

Paz, Octavio, Marcel Duchamp, The Viking Press, New York, 1978, p. 87.

Ibid. p.106. 
these apparently blank walls of sheets stand for the parentheses between which one becomes conscious of ones own being.

2892 also offers a means by which to reflect upon the creative trajectory of the artist himself by considering how the formal transitions of his work open themselves towards the spectator, the individual, the self. Within Senise's oeuvre, the image of the shroud appears as a process-symbol - or readymade symbol as Herkenhoff defined it - between Beijo do Elo Perdido (199I) and Quase Infinito (1992); concurrent with this, is Senise's use of doubling or mirroring methods of composition. The figure of the vase, as mentioned above, is one example, while in other works the gesture of doubling is more overtly imbued with sexuality. If we consider the Beijo and Quase Infinito as compositions that are themselves paired, interconnected themes emerge. The kiss as moebius strip, that infinite enveloping of outside and inside, is presented as the intersubjectivity of the self and other, body-less heads finding momentary unity in desire. When seen in conjunction with the latter work, the kiss however becomes shrouded in the certainty of finitude, in the ultimate impossibility of the fulfilment between the Self and the other.

By associating these two paintings the nonsensical concept of 'quase infinito' becomes related to the approach of the Self and the Other through the sexual act. An ontological question thus arises where we find something comparable with Sartre's notion of 'double reciprocal incarnation':

Thus the realisation of the 0ther's flesh is made through my own flesh; in desire and in the caress which expresses desire, I incarnate myself in order to realise the incarnation of the other.

Yet such reciprocal arrangement between oneself as flesh (being-initself) and one's own consciousness (being-for-itself) of the 0ther as flesh, can never be complete, it vanishes as soon as it is consummated, since "pleasure is the death and failure of desire $[\ldots]$ because it is not only fulfilment but its limit and end.'

The totalising bond between self and other, infinite in its consequences, is broken by the gaze: "In the primordial reaction to

\section{7}

Sartre, Jean-Paul, Being and Nothingness: an essay on phenomenological ontology (L'Être et le néant: Essai d'ontologie phénoménologique, originally published in 1943), Citadel Press, 200I, p.391.

Ibid. p.397. the Other's look I constitute myself as a look.' (p.393) For Sartre this confrontation of gazes can only lead to the submission of one and the domination of the other. Relations between Self and Other are in this sense either masochistic or sadistic.

Alex Potts writing on Winckelmann's $18^{\text {th }}$ century History of Art of Antiquity, comes to a similar conclusion to that of Sartre, only the object of the gaze is not flesh but its representation:

Wincklemann's prefiguration of a modern consciousness of the deadly stillness of the neoclassical nude works because, in his account, the blankness identified with the ideal figure, the stilling of emotion and desire in its perfected marble forms, is coupled with an intense awareness of the kinds of erotic and at times sadomasochistic fantasy that could be woven around such representations of the body beautiful. ${ }^{9}$

Senise's sheets in other words, need to be blank, they cannot even hint at the trace of representation contained in the shroud, since this would interfere with the consciousness of the spectator. The image of those bodies has to be denied otherwise a sexualised gaze emerges that disrupts the state of being-for-itself in the spectator. We have so far described a work that places the viewer between two blank walls. The viewer, now the subject of the work itself, stands between the site of conception and that of death. Both of these have taken place; they remain in a past that the viewer conceives in the present. The structure is a device that has two functions: to cause a space of separation (between work and world) from that which is beyond and to encourage in the viewer the awareness of her or his own condition of being. The work achieves this by rejecting any form of representation, because to do so would lead only to the constitution of one's own sense of being as a gaze. The architectural relation that the installation creates is therefore crucial. Heidegger writing on the Greek Temple in his renowned essay on The Origin of the Work of Art, claims that:

It is the temple-work that first fits together and at the same time gathers around itself the unity of those paths and relations in which birth and death, disaster and blessing, victory and disgrace, endurance and decline acquire the shape of destiny for human being. ${ }^{10}$

Potts, Alex, Flesh and the Ideal: Winkelmann and the origin of art history, Yale University Press, New Haven and London, 1994, p. 2. 
If we think of Senise's 2892 as equivalent to the vase that holds the ambivalent condition of being the space of conception and that of death, while also segregating that which surrounds it, then we can conclude that the installation produced a form of veiling of Montigny's neoclassical architecture that both obscures and frames it. It frames in so much as it summons such themes back into the building, emphasising even if unconsciously, the relation with the image of the corridor and Montigny's architecture.

Montigny, himself a product of the enlightenment, emerging in the wake of Jacques-Louis David and the rise of neoclassicism, imbued his designs with the ideal of architecture as the embodiment of reason. For the architectural historian Milton Vitis Feferman, Montigny's architecture can be framed within the context of the re-elaboration of the symbols of life and death within the neoclassical symbolic language:

0 lluminismo radical francês, base filosófica da revolução, é obviamente um movimento anticristão, anti-religioso e de caráter civil, que tinha como problema a substituição daquelas imagens religiosas por outras que não fossem apoiadas na tradicional cultura greco-romana.

Mesmo depois dos movimentos anti-religiosos, durante a revolução francesa, a imagem de uma caminhada rumo à transcendência continua a ser feita sob a forma de símbolos, que mostram como o ser humano pode transcender rumo a uma vida futura, desde que suas ações simples e positivas do presente sejam feitas, por exemplo, em prol do bem estar da sociedade."

Writing specifically on Montigny's symbolic language, Feferman elaborates on the implicit morality of the architecture:

A idéia de opor um templo inferior e um templo superior, idéia geradora que Grandjean perseguiu em seu projeto, apóia-se na associação de um templo superior iluminado oposto a um inferior

10

Heidegger, Martin, The Origin of the Work of Art, reprinted in: Martin Heidegger: Basic Writings, Harper \& Row, New York, Hagerstown, San Francisco, London, 1977, p. 168.

II

Feferman, Milton Vitis, 'Transferências imagéticas na arquitetura', Architextos 067.01, year 06, Dec 2005. <http://www.vitruvius.com.br/revistas/read/arquitextos/06.067/395>. Accessed November 2011 . obscurecido formando uma imagem dual entre a verdade radiante do caminho do bem em oposição ao erro e a sua obscura ambiência propicia para a autocontrição e expiação do erro.

Os dois espaços são simbolicamente interdependentes demonstrando que 0 erro e acerto são as duas faces de uma caminhada humana unitária em que uma depende da outra. A salvação se opõe à perdição no caminho da iluminação final. ${ }^{12}$

Judeo-Christian morality is implicit within the very notion of the Cartesian Cogito, since if we are aware of how things appear to us but not how they are in themselves, then such phenomena can only be understood as a product of our own mental contents. In order to avoid the solipsistic trap that this argument inevitably opens, Descartes would himself rely on Divine intervention as a form of reassurance that the world does in fact exist beyond the individual's consciousness. The very idea of reason therefore necessitated the transcendental self and the omnipresent divinity, the singularity and the totality.

Although speculation is rife on the meanings of Duchamp's Given, within this context it could be helpful to understand it as a comment on the fall (la chute) of the enlightenment (l'éclairage) through the invocation of the body. The neoclassical simplicity and grandeur of the human form is disrobed by Duchamp's juxtaposition of Reason with Voyeurism. The nude is taken off its plinth and left, discarded laying upon the landscape. It is as if the body by integrating nature rather than standing above it (as in Heidegger's Greek Temple), accompanies the libidinous act that transforms the apparatus of single point perspective into a peep show.

The unitary human path which is materialised through neoclassical architecture is similarly interrupted by the walls in 2892 . If we are to associate the Cartesian notion of Cogito, as analogous with the single point perspective (the self as gaze), then Sartre's 'dismembering' of the being through the disjunction between consciousness and flesh would require a form of doubling or mirroring device. In this way the symbolism invoked in neoclassical architecture, which relies on a 'unity of its paths' becomes fragmented by that which determines the very limits of the path: the mirroring of the sites of conception and death. The white walls that place the viewer between these limits, disrobe the transcendental self that the architecture addresses,

12

lbid. 
encouraging the awareness of the self as both being-in-itself and for it-self, as consciousness and flesh.

These speculations on the nature of an atypical work may in fact offer a means of thinking about the disjunction of sites in Senise's more recent work, which since 2000 often have relied on techniques of single point perspective. Not so much the baroque inability of leaving the work as it is, readymade, we find here a return to the process-symbol of the shroud where the imprint of decaying architectural surfaces such as floorboards are captured and reconstituted as perspective views of structures that could either be in construction or in decomposition. The point of view from which these perspectives are constructed is frequently positioned from the ground. It is as if the observer is lying down, fallen to the floor. Like the figure in Given, it is not clear whether the position is one of demise or rest, or whether the spectator, placed on the floor, displaced from her/his vantage point remains a voyeur or has become the very subject of the work. That to which the shroud refers to.

DR MICHAEL ASBURY: is an art critic, art historian and curator. He is Reader in the theory and history of art at the University of the Arts London, where he is also a memb er of the Transnational Art, Identity and Nation (TrAIN) research centre and the CCW graduate School. 
